\title{
RESOCJALIZACJA KOBIET OSADZONYCH ZA PRZESTEPSTWA NA TLE PRZEMOCOWYM
}

\begin{abstract}
Abstrakt: Podstawowym celem wychowania resocjalizującego jest przystosowanie jednostki do życia w społeczeństwie, ale też wykształcenie w niej cech osobowości i zachowania, które pozwolą jej na samodzielne, prawidłowe funkcjonowanie w społeczeństwie. Kobiety, które dopuściły się różnych przestępstw na tle przemocowym, poddawane są w zakładach karnych szeregowi działań mających wywołać konkretną, zamierzoną zmianę lub zmodyfikować agresywne zachowania. Podstawowe formy oddziaływań w tym obszarze to umożliwianie kontaktu z rodziną lub wspólne przebywanie matki i dziecka w zakładzie karnym, resocjalizacja przez pracę, uczestnictwo w programach resocjalizacyjnych dedykowanych osobom stosującym przemoc, a także nagradzanie i karanie według założeń ekonomii punktowej. Doświadczenia różnych zakładów karnych udowadniają skuteczność i potrzebę realizowania tego typu działań.
\end{abstract}

Słowa kluczowe: motywacje przestępczości, model osobowości przestępczyni, akty przemocy, wychowanie resocjalizujące, programy resocjalizujące

\section{KOBIETA JAKO SPRAWCZYNI PRZESTĘPSTWA}

Mahatma Gandhi powiedział kiedyś, że dobro i zło muszą istnieć obok siebie, a człowiek powinien dokonywać wyboru. Każdego dnia dokonujemy więc rozmaitych wyborów wynikających z sytuacji, w jakich stawia nas życie. Oznacza to, że dylematy moralne wpisane są w życie każdego człowieka i uzależnione od wyznawanego przez nas systemu wartości. Psychika zbrodniarzy interesuje ludzkość, a zło, nie wiedzieć czemu, jest bardziej fascynującym tematem niż dobro. Co ciekawe, owo zło dokonywane przez kobiety stanowi przedmiot zainteresowania wielu badaczy z różnych dziedzin. Kobiecie, jako istocie z racji swej 
powierzchowności powszechnie uznawanej za słabą, łagodną i niewinną, społeczeństwo powierzyło rolę tej, która daje życie oraz je piastuje. Pełnienie przez kobietę funkcji matki i strażniczki domowego ogniska redukowało skłonność do zachowań agresywnych, dając pierwszeństwo tym, które miały zapewnić poczucie bezpieczeństwa i stabilności. Nie znaczy to, że zostały one całkowicie wyeliminowane, wszak kobieta musiała zadbać o przetrwanie swoje i potomstwa, jednakże to zadanie spoczywało głównie na mężczyznach, dlatego w sytuacji kobiety schodziło na dalszy plan. Mimo tego, jak obserwujemy od zarania dziejów, kobieta jest zdolna do popełniania czynów przestępczych, które w powszechnym mniemaniu zwykliśmy przypisywać mężczyznom.

W literaturze fachowej zależności między płcią a przestępczością badane są w trzech kontekstach: łamania prawa, czyli występowania różnic płciowych między sprawcami przestępstw, wiktymizacji, czyli podatności na stanie się ofiarą przestępstwa, oraz kryminalizacji faktycznej, czyli zróżnicowanej reakcji systemu sprawiedliwości karnej w zależności od płci sprawcy (Błachut 2001, s. 163).

Jedną, niebudzącą wątpliwości, stałą jest fakt, że to mężczyźni popełniają więcej przestępstw niż kobiety. Nie da się temu zaprzeczyć, choć równie niezaprzeczalną prawidłowością jest stale rosnący odsetek kobiet dopuszczających się łamania prawa.

Mamy więc do czynienia nie tylko ze wzrostem liczby przestępstw popełnianych przez kobiety, ale także ze zmianą w obrębie ich rodzajów. Marian Cabalski sugeruje, że „kobiety walczące o miejsce na rynku zatrudnienia przejęły od mężczyzn styl i sposoby konkurowania, nierzadko upodobniając się do nich również w sferze ich nagannych moralnie i sprzecznych z prawem wzorców postępowania" (Cabalski 2014, s. 23). Nie tylko zatem zmiana sytuacji na rynku pracy, ale też i inne czynniki, takie jak odmienne od dotychczasowych oczekiwania co do związków i postrzegania modelu rodziny, musiały wpłynąć na statystykę.

\section{MOTYWACJE PRZESTĘPCZOŚCI KOBIET}

Niezwykle ciekawą typologię zabójstw wskazuje Józef Gierowski. Wyróżnia on zabójstwa podyktowane motywacją ekonomiczną, seksualną, urojeniową, zemsty oraz motywacją związaną z poczuciem krzywdy lub zagrożenia. Właściwie kobiety mogą potencjalnie popełniać przestępstwa, kierując się wszystkimi z wyżej wymienionych motywacji, jednakże większość z nich związana jest z poczuciem krzywdy i zagrożeniami, jakie odczuwają, żyjąc u boku domowego tyrana. Statystyki wskazują, że jest ich ok. 39\% (Gierowski 1989, s. 95-172).

Kobiety najczęściej pozbawiają życia osoby najbliższe - partnera lub dziecko. Ich średnia wieku mieści się w granicach 30-35 lat, co znaczy, że dopuszczają się 
przestępstwa później niż mężczyźni. Trudno wskazać jednoznacznie środowisko, z którego wywodzą się zbrodniarki, albowiem i poziom inteligencji, i pochodzenie bywają różne, chociaż gdy mowa jest o zabójstwie domowego tyrana, to znacznie częściej dochodzi do niego w rodzinach o niższym statusie ekonomicznym i wiąże się z nieprzerwanie skrajną relacją zachowań dysfunkcyjnych, w której mężczyzna (jak wskazuje Magdalena Budyn-Kulik) tyranizuje kobietę. Ta relacja, często przejawiająca się również przez zmiany w psychice kobiety, takie jak powstanie syndromu batteredwomen (bitej kobiety), z której żadna ze stron nie umie się wydostać, a otrzymana pomoc jest nieskuteczna, może powodować, że kobieta w akcie samoobrony i uwolnienia długotrwałego, skrywanego napięcia dopuści się zabójstwa dręczącego ją partnera. W takiej sytuacji zabójstwo przeważnie nie wiąże się z żadnym zamiarem (a często dochodzi do niego w warunkach obrony koniecznej lub pod wpływem silnego, usprawiedliwionego okolicznościami wzburzenia, czyli w tak zwanym afekcie), a jest jedynie tragiczną reakcją spustową na stresogenną sytuację (Goźlińska 2013).

\section{MODEL OSOBOWOŚCI PRZESTĘPCZYŃ}

Na podstawie literatury socjopsychologicznej i codziennej obserwacji przejawów życia licznych rodzin można dokonać próby stworzenia zarysu cech osobowości kobiety, która dopuszcza się przemocy wobec bliskich. Sprawczyni przemocy i jej ofiara są elementami stałego wzajemnego oddziaływania na siebie, które Jurg Willi, niemiecki psychoanalityk, nazywał terminem „koluzja”. Definiował go jako nieuświadomiony „konflikt przeniesiony z dzieciństwa, wzajemnie rozgrywany przez partnerów, w którym jeden przyjmuje postawę progresywną, a drugi regresywną. Konflikt ten może przebiegać wokół kwestii dawania i przyjmowania opieki, kontrolowania i bycia kontrolowanym, niewierności i zazdrości, władzy i poddania” (Cabalski 2014, s. 339). Zdaniem niemieckiego psychoanalityka jednostki podświadomie wybierają na partnerów takie osoby, które będą pasowały do ich nierozwiązanych we wczesnych latach dzieciństwa konfliktów wewnętrznych. Jedną ze stron tego konfliktu wypierają z siebie i przenoszą na partnera, wyznaczając tym samym sztywne role małżeńskie. Idea koluzji i praktyka psychoanalityczna dowodzą, że w sytuacjach przemocy skuteczna może się okazać wnikliwa i właściwie ukierunkowana terapia.

Kiedy natomiast energia koluzji wykracza poza sferę psychiczną obojga małżonków, to znaczy impulsy agresji nie są już powściągane siłą myśli, ale angażują również ciało człowieka (dochodzi do zadawania uderzeń, rzucania 
przedmiotami i używania innych form przemocy fizycznej), rokowania terapeutyczne - według J. Williego - są znacznie trudniejsze (Cabalski 2014, s. 339).

Niewątpliwie źródeł wszelkiego rodzaju aktów przemocy, a co za tym idzie potencjalnych konfliktów małżeńskich, należy doszukiwać się we wczesnych fazach rozwoju jednostki. Nie od dziś bowiem wiadomo, że w życie dorosłe wkraczamy z olbrzymim „bagażem właściwości przejętych od swoich przodków (podobieństwo wyglądu i reakcji psychicznych, naśladownictwo zachowań ojców i matek, powtarzanie błędów rodziców w procesie wychowania dzieci itp.)" (Cabalski 2014, s. 339). Tak więc zachowanie zarówno kobiet, jak i mężczyzn wynika z faktu, że odgrywają oni role swoich matek i ojców zapamiętane z dzieciństwa, ale przeniesione już na nowy grunt. Przy tym nie uświadamiają sobie faktu, że ich zachowanie nie wynika $\mathrm{z}$ indywidualnych cech i świadomych wyborów, ale jest swego rodzaju kalką postaw rodziców. Przykładem najlepiej ilustrującym to założenie jest zespół DDA - Dorosłych Dzieci Alkoholików, które nauczyły się żyć w rodzinie z problemem alkoholowym, ale przez to nie potrafią sobie poradzić $\mathrm{w}$ domu bez takiego problemu. Podobnie jest zresztą z dziećmi, które wychowywane były $\mathrm{w}$ rodzinach dotkniętych innego rodzaju dysfunkcjami i patologiami (przemoc małżeńska i rodzicielska, nadużycia seksualne, nadmierna kontrola, zakaz wyrażania emocji, izolowanie od ludzi itp.) (Cabalski 2014, s. 340-341). Cabalski dostrzega tu mechanizm błędnego koła, ponieważ praktyka dowodzi, że skutki przemocy stosowanej przez rodziców rzutują na życie ich synów i córek, a nawet wnuków i dalszych pokoleń, nakręcając w ten sposób spiralę wadliwej socjalizacji. Właściwym rozwiązaniem staje się według niego zabieg nakreślenia profilu osobowości kobiety dopuszczającej się przemocy, który będzie miał nie tylko walory poznawcze, ale i metodologiczne. Podstawową cechą ujawniającą się w tym modelu jest, zdaniem Cabalskiego, androgyniczność kobiety, która sprawia, że zachowuje się ona jak mężczyzna, a kobiece cechy przesuwa na drugi plan. Ponadto w profilu psychologicznym znajdują się także takie cechy, jak:

- wrogość w stosunku do otoczenia;

- gwałtowna i niemożliwa do powstrzymania agresywność;

- nastawienie na rywalizację i demonstrowanie otoczeniu swojej szczególnej pozycji;

- wykazywanie ambicji bycia głównym decydentem we wszystkich sprawach dotyczących związku i rodziny;

- skłonność do prowokowania konfliktów, zmienność nastrojów, niecierpliwość, tendencja do silnych afektów (wpadanie w najwyższe rejestry oburzenia wyrażanego krzykiem, przekleństwami i złorzeczeniem), łatwość przechodzenia do rękoczynów i rzucania wszystkim, co wpadnie w ręce; 
- brak empatii wobec ofiar, niezdolność do reagowania na wielokrotnie powtarzane prośby o zaprzestanie dyskryminacji, brak pozytywnej reakcji na jakiekolwiek perswazje (Cabalski 2014, s. 342-343).

Nakreślenie zatem takiego portretu psychologicznego powinno stać się podstawą do właściwej resocjalizacji kobiety dopuszczającej się aktów przemocy.

\section{AKTY PRZEMOCY}

Przemoc, zdaniem Ireny Pospiszyl, to:

wykorzystanie w kontaktach międzyludzkich przewagi sprawcy, aby realizować jego własne cele. Dokonuje się ona przez naruszenie praw osobistych drugiego człowieka, manipulowanie, nieliczenie się z dobrem osoby poddanej przemocy, powodowaniem cierpienia. Najczęściej występuje w postaci mniej drastycznej, a sprawcy przemocy nierzadko definiują swoje zachowanie jako działanie na rzecz ofiary, dla jej dobra (Pospiszyl 2008, s. 57).

Dręczenie człowieka rzekomo dla jego dobra to nie tylko najczęstsza forma przemocy, ale też niosąca ze sobą nieodwracalne szkody w psychice człowieka. Należy więc zaznaczyć, że przemocą jest każdy celowy akt, który nie tylko wykorzystuje przewagę sprawcy, ale również godzi w osobistą wolność jednostki, doprowadza do jej fizycznej lub psychicznej szkody i wychodzi poza społeczne normy wzajemnych kontaktów, albo też wszelkie akty udręczenia i okrucieństwa (Pospiszyl 2008, s. 57). Aby można było mówić o akcie przemocy, należy wziąć pod uwagę trzy podstawowe warunki:

- sprawca dopuszcza się przemocy, bo czuje się bezkarny,

- jego zachowanie narusza dobro i prawa ofiary,

- działając, realizuje wyłącznie swoje potrzeby, a nie ofiary.

Definicja przemocy pojawia się także w ustawie o przeciwdziałaniu przemocy w rodzinie z 29 lipca 2005 roku:

Przemoc w rodzinie należy rozumieć jako jednorazowe lub powtarzające się umyślne działanie lub zaniechanie naruszające prawa lub dobra osobiste osób, w szczególności narażające te osoby na niebezpieczeństwo utraty życia, zdrowia, naruszające ich godność, nietykalność cielesną, wolność, w tym seksualną, powodujące szkody na ich zdrowiu fizycznym lub psychicznym, a także wywołujące cierpienia i krzywdy moralne u osób dotkniętych przemocą (art. 2, pkt 2 - Dz. U. z dnia 20 września 2005 r. Nr 280, poz.11493). 
Literatura fachowa wskazuje cztery podstawowe formy przemocy:

- przemoc fizyczna,

- przemoc psychiczna (lub emocjonalna),

- przemoc seksualna (nadużycia seksualne),

- zaniedbanie.

W rzeczywistości jednak trudno mówić o jednorodnych formach przemocy, ponieważ są one ze sobą bardzo ściśle powiązane, a to oznacza, że elementy jednej mieszają się z inną lub z jej innymi formami. I tak przemoc fizyczna pozostaje w ścisłym związku z przemocą emocjonalną, a przemoc seksualna z emocjonalną i oczywiście fizyczną (Pospiszyl 2008, s. 58).

Inną propozycję podziału form przemocy zaproponował Jerzy Mellibruda:

- przemoc gorąca - u jej podstaw leży furia, czyli dynamiczne i naładowane gniewem zjawisko pękania tzw. tamy emocjonalnej, uruchamiające agresywne zachowanie (furia rozumiana jest jako wybuch skumulowanych i niemożliwych do powstrzymania uczuć złości lub wściekłości);

- przemoc chłodna - polega na realizowaniu przez sprawcę ściśle określonego scenariusza zapisanego w jego umyśle, a czasem również w obyczajach i środowiskowej kulturze (sprawca przemocy zmierza do określonego celu, dla którego jest gotowy wtargnąć w psychikę ofiary, przy czym znajduje usprawiedliwienie dla swego działania nawet wtedy, gdy jest świadomy cierpienia, które spowodował) (Mellibruda).

\section{WYCHOWANIE RESOCJALIZACYJNE}

Wychowanie resocjalizacyjne, zdaniem Czesława Czapówa i Lesława Pytki, to nie tylko działalność teoretyczna, ale i praktyczna. Zasadniczym jego zadaniem jest wychowanie osób z zaburzeniami w procesie socjalizacji, czyli osób, które z rozmaitych powodów wykazują objawy nieprzystosowania społecznego i dopuszczają się przestępstw.

Nazwać je można działalnością teoretyczną, ze względu na wypracowany pewien zespół twierdzeń teoretycznych, czyli zależności o stosunkowo wysokim stopniu ogólności. Można ją także nazwać działalnością praktyczną, gdyż wypracowała metody wychowania w różnych typach społeczeństw i okresach historycznych (Pytka 1991, s. 112).

Podstawowym celem wychowania resocjalizującego jest zatem przystosowanie jednostki do życia w społeczeństwie, ale też wykształcenie w niej cech osobowości 
i zachowania, które pozwolą jej na samodzielne, prawidłowe funkcjonowanie. Wszelkie normy i wartości, które w tym społeczeństwie obowiązują, jednostka zresocjalizowana powinna nie tylko respektować, ale też uznać za właściwe. Czapów z kolei metodykę wychowania resocjalizacyjnego zdefiniował jako „system sformułowań wskazujących zadania, środki i sposoby, których respektowanie umożliwia zbliżanie się do pożądanego stanu rzeczywistości” (Kwieciński, Waligóra 2007, s. 213).

Metodyka w tym kontekście to zbiór zaleceń dotyczących środków, posługiwania się nimi oraz procedur celowościowego działania, a zatem przynosi tylko pewne pomysły i wskazówki, z których wychowawcy swobodnie mogą korzystać, dostosowując swe wybory do indywidualnych przypadków. Z kolei środki oddziaływania resocjalizacyjnego to ściśle określone formy działania, które mają zmierzać do wywołania konkretnej, zamierzonej zmiany lub zmodyfikowania pewnych zachowań zgodnie ze społecznie akceptowanymi standardami. Są one bardzo ściśle określone w aktach prawnych regulujących wykonanie kary pozbawienia wolności, a kodeks karny wykonawczy przewiduje zróżnicowanie zarówno metod, jak i środków w zależności od kategorii osadzonych, systemu wykonania kary oraz typu i rodzaju zakładu karnego. Można je podzielić według kryterium stosowanego narzędzia na procedury:

- $\quad$ psychotechniczne - psychotechnikę Lesław Pytka definiuje jako technikę więzi dwuosobowej, która wykorzystuje zależności osobowe o charakterze indywidualnym w codziennych kontaktach interpersonalnych. Opiera się ona na trafnym doborze i zastosowaniu środków wpływu osobistego w zaspokajaniu potrzeb osoby poddanej procesowi wychowania i terapii. Procedura ta pozwala na znaczny stopień identyfikacji psychologicznej wychowawcy i podopiecznego oraz indywidualny rozwój osoby poddawanej oddziaływaniu;

- socjotechniczne - socjotechnika to, zdaniem Pytki, procedura, w której narzędziem jest grupa wychowawcza i wpływ grupowy. W procedurze tej wykorzystuje się więzi wewnątrzgrupowe i międzygrupowe do zaspokajania potrzeb wychowywanych, ich uspołeczniania oraz terapii. Procedura ta umożliwia wzrost poziomu dojrzałości interpersonalnej wyrażającej się adekwatnym postrzeganiem i ocenianiem zachowań cudzych i własnych w kontekście społecznym;

- kulturotechniczne - kulturotechnika rozumiana jest przez Pytkę jako procedura wykorzystująca dobra kultury i cywilizacji, którymi wychowawca może modyfikować przekonania, uczucia i zachowania osób pozbawionych wolności. Polega ona na zastosowaniu w opiece, wychowaniu i terapii środków wpływu wywieranego przez kulturę i cywilizację 
(film, sztuka teatralna, powieść, wykład). Procedura ta pozwala osiągnąć cel, którym jest ponowna integracja jednostki z kulturą (Kwieciński, Waligóra 2007, s. 214).

Aby oddziaływania penitencjarne były skuteczne, należy jednak prawidłowo ocenić wyjściowy stan osobowości jednostki, która ma być im poddana oraz zbadać wpływy społeczne, jakim poddawana była w przeszłości. Nie bez znaczenia pozostaje także poziom kwalifikacji i umiejętności kadry pedagogicznej, wychowawcy bowiem muszą precyzyjnie wyznaczać cele operacyjne dostosowane nie tylko do indywidualnych przypadków, ale także do własnych predyspozycji i możliwości. Dodajmy do tego specyfikę klimatu, jaki tworzą placówki penitencjarne (wynikającą ze stosunków interpersonalnych między pracownikami i osadzonymi), stopień autonomiczności osobistej wychowywanych oraz charakter kontroli pedagogicznej (opiekuńcza czy represyjna). Wszystkie te czynniki bowiem decydują o efektywności działań resocjalizacyjnych.

Do środków oddziaływań resocjalizacyjnych przewidzianych w kodeksie karnym wykonawczym zaliczamy: podtrzymywanie więzi z rodziną, zatrudnienie, nauczanie, działalność kulturalno-oświatową i zajęcia sportowe, nagrody i kary dyscyplinarne, praktyki religijne, profilaktykę przeciwalkoholową (Kwieciński, Waligóra 2007, s. 215).

\section{PODTRZYMYWANIE WIĘZI Z RODZINĄ}

Kontakty skazanej z rodziną to bardzo ważny czynnik umożliwiający powrót do życia na wolności po odbyciu kary. Nie chodzi tu tylko i wyłącznie o widzenia z partnerem, ale także o spotkania z rodzicami, rodzeństwem czy dalszymi krewnymi. Świadomość tego, że ktoś pamięta o skazanej, ma chęć odwiedzenia jej i przekazania informacji o tym, co dzieje się na zewnątrz, poza murami więzienia, w sposób znaczący ułatwia proces resocjalizacji. Dodatkowym czynnikiem jest tu także macierzyństwo. Jeśli kobieta ma kontakt z dzieckiem, ma możliwość wychowywania go w placówkach do tego przystosowanych (takich jak Zakład Karny w Krzywańcu, w którym skazane mogą przebywać wraz z dziećmi), efektywność procesu resocjalizacji znacznie wzrasta. System programowego oddziaływania tego typu, czyli dla osadzonych matek wraz z dziećmi, dotyczy aspektów: edukacyjnego, wychowawczego, terapeutycznego i resocjalizacyjnego. Dzięki macierzyństwu kobieta osadzona jest poddawana modelowaniu według wzorca odpowiedzialnej matki. To bardzo ważne, ponieważ większość z tych kobiet nie miała w dzieciństwie szansy, by poznać właściwe postawy rodzicielskie, a co za tym idzie - nie potrafi w sposób właściwy opiekować się dzieckiem, nie wspominając już o prawidłowym 
wychowywaniu i socjalizowaniu własnej pociechy. Przebywanie skazanych wraz $\mathrm{z}$ dzieckiem uczy je więc nie tylko nowej roli, ale też daje poczucie spełnienia, szansę odnalezienia celu w życiu i wyrwania się z jedynego znanego im stylu życia.

\section{PROGRAMY REDUKUJACE AGRESJE I PRZEMOC}

W przypadku przestępstw przemocowych niezwykle istotne jest stosowanie programów resocjalizacyjnych redukujących agresję i przemoc. Programy mające na celu redukowanie u więźniów nastawień agresywnych są stosowane wobec dwóch kategorii osadzonych: osób demonstrujących zachowania agresywne na terenie więzienia, w interakcjach z innymi więźniami i sprawców przestępstw charakteryzujących się agresją i przemocą.

Jeden z przykładów takiego programu opublikował Krzysztof Linowski. Stworzył on wraz z zespołem i wypróbował w Areszcie Śledczym w Radomiu program leczenia postaw agresywnych (redukowania skłonności do agresji) rozpisany na 31 dni. Jego istotą jest organizowanie skazanym czasu w taki sposób, by zmniejszyć ilość chwil wolnych. Podczas każdego z 31 dni uczestnicy biorą udział w specjalnych miniwykładach i ćwiczeniach stanowiących segmenty całego programu. Z kolei każdy segment realizuje konkretne, z punktu widzenia celów programu, ważne hasła, m. in.: „Poznajmy się”, „Moje przekonania na temat przemocy”, „Konsekwencje stosowania przemocy”, „Moje potrzeby”, „Lista emocji”, „Moja hierarchia wartości”, „Moja droga życia”, trening asertywny (w poszerzonym wymiarze), „Empatia”, „Nasza grupa”, „Słuchanie”, „Informacje zwrotne”, „Rozwiązywanie konfliktów w grupie”, „Potrzeba bezpieczeństwa i opieki”, „Potrzeba prestiżu i uznania”, „Komunikowanie ludziom swoich emocji i rad”, „Napaść”, „Moja największa wada i zaleta”, „Kierowanie własnym rozwojem”, „Jaki jestem? Jaki chciałbym być?”, „Przyczyny i konsekwencje konfliktów interpersonalnych”, „Rozwiązywanie konfliktów interpersonalnych”, „Poniżani”, „Efektywne radzenie sobie z własnym i cudzym stresem”, „Styl działania bez przemocy”. Program wzbogacony jest także ćwiczeniami oddechu oraz zajęciami sportowymi, co zmusza skazanych do znacznej aktywności (Machel 2006, s. 230).

Kobietom, które mają za sobą wiele negatywnych doświadczeń, program niesie szereg korzyści. Tego typu oddziaływania nie tylko przeciwdziałają nudzie, ale przede wszystkim uczą osadzone tego, jak prawidłowo funkcjonować w społeczeństwie po opuszczeniu zakładu karnego. Dotychczas nikt ich nie uczył produktywnego spędzania czasu, radzenia sobie z własną frustracją lub agresją otoczenia.

Program uwzględniający terapię Gestalt to kolejny przykład działań adresowanych do więźniów, sprawców przestępstw z użyciem przemocy wobec osób 
bliskich. Przygotowała go wraz ze swoimi współpracownikami Magdalena Chojnacka. Podstawowe cele pracy z grupą skazanych to: poznać siebie, radzić sobie ze złością, radzić sobie z trudnymi emocjami i stresem, nauczyć się zauważać problemy i stanowisko innych, radzić sobie z sytuacją patową i bezradnością, uporządkować swój system wartości, wypracować plan własnego życia po opuszczeniu zakładu karnego i radzić sobie z takimi czynnikami ryzyka, jak: problemy finansowe, bezrobocie, izolacja społeczna, uzależnienia.

Założeniem programu była całkowita dobrowolność, a ci, którzy wyrazili chęć uczestniczenia $\mathrm{w}$ zajęciach, zawierali kontrakt z realizującymi je psychologami. Zajęcia prowadzone były w sześciu blokach. Pierwszy to poznawanie się - uczestnik w ciągu dwóch minut miał przedstawić swoją biografię. Blok drugi został nazwany Piramida wartości i wymagał od uczestników ujawnienia ważnych dla nich wartości, którymi kierują się w życiu. Blok trzeci o nazwie Moja droga do celu uruchamiał wyobraźnię uczestników w zakresie dążenia do celu i sposobu jego realizacji. Blok czwarty został nazwany Przeszkody na mojej drodze do celu. Tu uczestnicy pomocy terapeutycznej musieli dorysowywać rozmaite progi, które mieli do pokonania na drodze do osiągnięcia wyznaczonego celu. Podczas realizacji bloku piątego, który nazwano Znaczące osoby, uczestniczący terapii mieli narysować osoby im bliskie. Blok szósty Niedokończone sprawy realizowano w małych podgrupach. Dotyczył on spraw niedokończonych na wolności, źle realizowanych, których dokończenie miało istotne znaczenie zarówno dla nich samych, jak i dla ich najbliższych. Autorka programu podkreśla, jakie pod wpływem terapii zmiany dostrzegli u siebie skazani: poprawa wglądu w siebie - lepsza samoświadomość, wzrost akceptacji i szacunku dla samego siebie, lepsze rozumienie swojego zachowania oraz innych ludzi, poprawa umiejętności komunikowania się z innymi, wzrost poczucia odpowiedzialności za siebie i swoje czyny, zwiększenie się stopnia otwartości i zaufania w relacjach interpersonalnych, lepsze radzenie sobie z trudnymi sytuacjami w zakładzie karnym (Machel 2006, s. 230-233).

Wśród programów resocjalizacyjnych należy wymienić program redukujący agresję i przemoc $\mathrm{w}$ rodzinie. Jest to projekt edukacyjno-korekcyjny adresowany do osób stosujących agresję i przemoc w rodzinie, skazanych dorosłych i młodocianych. Realizuje się go w Zakładzie Karnym we Włocławku. Celami naczelnymi programu są: modyfikacja postaw sprawców przemocy w rodzinie oraz wygaszenie tych postaw i zastąpienie ich postawami prorodzinnymi. Jego autorką jest psycholog Dorota Śniegowska. Oparła swój pomysł na dwóch częściach - grupowej i indywidualnej. Część grupowa to działania dydaktyczne dotyczące rodziny, życia i szczęścia rodzinnego, wychowania w rodzinie, odpowiedzialności rodziców za dzieci i za przygotowanie ich do dorosłości, zjawisk patologicznych w rodzinie i ich skutków dla młodych i dorosłych członków rodziny. Realizatorzy wzbogacają 
zajęcia o dyskusje na temat umiejętności wzięcia na siebie odpowiedzialności za własne naganne i przestępcze postępowanie przeciwko swojej rodzinie. Dodatkowo uczestnicy programu oglądają specjalnie dobrane filmy fabularne na temat agresji i stosowania przemocy w rodzinie. W części grupowej realizuje się działania psychokorekcyjne, których celem jest nauczenie skazanych kontrolowanego przeżywania takich emocji, jak złość i gniew oraz umiejętności wyrażania empatii, asertywnego odnoszenia się do bliskich i porozumienia się bez wykorzystywania przemocy. Końcowym elementem programu jest trening asertywnych zachowań abstynenckich. Realizacja programu przewiduje 15 dwugodzinnych zajęć edukacyjnych i psychokorekcyjnych o charakterze zbiorowym. Oprócz zajęć zbiorowych uczestnicy korzystają $\mathrm{z}$ indywidualnych porad i konsultacji personelu realizującego program. Na zakończenie piszą pracę, w której prezentują swoje aktualne rozumienie odpowiedzialności za utrzymanie poprawnych stosunków w rodzinie (Machel 2006, s. 233-234).

Metoda bardzo pomocna w pracy resocjalizacyjnej kobiet to Trening Zastępowania Agresji (ART). Program ów stanowi metodę korygowania agresywnych zachowań u osób skazanych. TZA to program profilaktyczny, którego celem jest zmiana agresywnych oraz przemocowych zachowań na zachowania pożądane oraz społecznie akceptowane. ART polega na wielostronnej interwencji nakierowanej na zmianę zachowań agresywnych w danej grupie.

U kobiet skazanych często spotyka się różnego typu problemy natury psychicznej oraz emocjonalnej, dlatego pomocna okazuje się Racjonalna Terapia Zachowania (RTZ), która stanowi zgodny i wielostronny system psychologiczny opierający się na innowacyjnej teorii uczenia się, neurofizjologii i na ponadkulturowych oraz odwiecznych zasadach związanych z pracą ludzkiego mózgu. RTZ za pośrednictwem technik samopomocy uczy pomagania samemu sobie, radzenia sobie $\mathrm{z}$ codziennymi kłopotami czy stresem, samodzielnego stawiania sobie zdrowych celów i ich osiągania, jak również zapobiegania nawrotowi problemu.

Metodę tę zalicza się do grupy metod o charakterze poznawczo-behawioralnym, które polegają na tym, że uczestnik treningu, przeprowadzając poznawczą analizę sytuacji, w której był obecny lub jest obecny, oraz korzystając z umiejętności modelowania i systemu pozytywnych wzmocnień, doprowadza do modyfikacji swojego zachowania. Jest to program korygujący agresywne zachowania. Podstawa treningu swoje źródło ma w zasadach teorii społecznego uczenia się. Metoda ta zawiera podstawowe „kroki”, które dają możliwość nabywania danych umiejętności społecznych oraz ich wypróbowanie w trakcie odgrywanych scenek (Morawski 2004, s. 27).

Fakt niedostosowania do życia według norm, a w tym agresja, stanowi zatem przejaw braku umiejętności zachowań społecznych. Agresja to przede wszystkim zachowanie wyuczone na podstawie obserwacji, naśladownictwa, bezpośredniego 
doświadczenia oraz powtarzania. To oznacza, że człowiek uczy się takich umiejętności, jak: manipulacja, kłamstwo, złośliwość, znęcanie się, ale też się innych, jak: altruizm, współpraca oraz empatia. Nauka ta odbywa się przede wszystkim przez doświadczenia obserwacyjne, podczas których widzi się zachowanie innych osób wynagradzanych za swoje zachowanie, bądź przez doświadczenia bezpośrednie, tj. własne zachowanie, które w ocenie własnej przynosi nam korzyści oraz za które otrzymuje się nagrody. Trening TZA-ART składa się z trzech komponentów: treningu umiejętności prospołecznych - wymiar behawioralny; treningu kontroli złości - wymiar emocjonalny; treningu wnioskowania moralnego oraz wartości - wymiar poznawczy, kognitywny.

Zmiana zachowań dokonuje się za pośrednictwem: modelowania (wzór odpowiedniego wykonania określonej umiejętności do naśladowania), odgrywania ról, informacji zwrotnych, generalizacji i transferu, czyli wykorzystania doskonalonych umiejętności w praktyce życia codziennego.

Trening kontrolowania polega na tym, że uczestnicy przygotowują na każdą z sesji opis pewnych sytuacji, które wywołały złość, a następnie identyfikują czynniki, które spowodowały te uczucie (wydarzenia zewnętrzne oraz dialog wewnętrzny będące powodem złości), oraz sygnały (własne doświadczenia, np. napięcie mięśniowe, zaciśnięte pięści dające możliwość określenia odczuwanych emocji jako złość), uczą się używania reduktorów (technik wykorzystywanych do zminimalizowania poziomu gniewu, np. głębokich oddechów, liczenia wstecz, wyobrażenia sobie spokojnej sytuacji lub odległych skutków czyjegoś zachowania), stosowania monitów (dialogu wewnętrznego na przykład: „zachowaj spokój”, „panuj nad sobą” bądź wyjaśniania cudzych zachowań jako niewrogie) i wykorzystywania samooceny (na ile dobrze zrealizowali powyższe kroki; nagradzają także siebie za efektywne wykonanie) (Goldstein 2004, s. 65).

Cel treningu wnioskowania moralnego to cofnięcie opóźnień występujących w rozwoju moralnym osób, które zachowują się w sposób agresywny. Wychowanie moralne występujące $\mathrm{w}$ programie TZA opiera się na jednej strategii, którą stanowi dyskusja o dylematach moralnych. Osoby stojące na czele grupy wspierają najbardziej dojrzałe decyzje oraz ich moralne uzasadnienie. Trening wnioskowania moralnego składa się ze zwiększenia poczucia przyzwoitości sprawiedliwości i uwzględniania praw oraz potrzeb innych osób (Potempska, Kołodziejczyk 2001).

Zajęcia prowadzi się w formie dyskusji, a czasem w formie odgrywania ról. Istotą wnioskowania moralnego jest zapoznanie z grupą dotkliwych problemów, które wymagają podania propozycji ich rozwiązania. Podczas treningu z indywidualnych propozycji wybiera się wspólnie rozwiązania, które są najbardziej dojrzałe moralnie. Trening ten to najnowszy komponent TZA. Wprowadzono go do programu, gdyż znacznie zwiększa jego skuteczność w zapobieganiu agresji wśród ludzi. Cel 
treningu to wywołanie dysonansu poznawczego oraz refleksji w stosunku do własnej hierarchii wartości w duchu daleko zmierzającej tolerancji i nadawanie pozytywnej roli emocjom, uczuciom, postawom oraz przekonaniom, co jest podstawą edukacji moralnej. Opóźnienie występujące w rozwoju moralnym interpretuje się jako posługiwanie się sądami moralnymi o charakterze niedojrzałym, hedonistycznym i egocentrycznym, u podstaw których znajdują się zniekształcenia poznawcze (czyli błędy myślowe) dotyczące egocentryzmu, umniejszania, zmiany znaczenia, obwiniania innych, zakładania najgorszego. Wprowadzeniem do treningu wnioskowania moralnego są ćwiczenia mające na celu odkrycie wartości przez wywołanie dysonansu poznawczego oraz dyskusje o problemach moralnych. Przedmiotem dyskusji są dylematy moralne, natomiast uczestnicy poszukują rozwiązań oraz argumentów, które uzasadniają ich wybór. Uczą się też podejmować decyzje moralne przez odpowiedzenie na pytanie, jaka jest podstawowa wartość każdego ludzkiego działania. Procedury owe dążą do dokonania poprawy w związku z opóźnionym rozwojem społeczno-moralnym za pośrednictwem ułatwienia pokonywania następnych faz rozwoju moralno-poznawczego. Chodzi o to, by uczestnicy treningu potrafili podejmować dojrzalsze decyzje w sytuacjach społecznych przez wybieranie zachowań prospołecznych i redukujących zachowania antyspołeczne. Są to procedury, które uczą sprawiedliwości, właściwego rozumienia społecznych problemów, liczenia się z prawami oraz potrzebami innych osób.

\section{ZATRUDNIENIE}

Praca, którą odbywają skazani w więzieniu, wiąże się z zasadą normalności, a więc z uznaniem normy obowiązującej w społeczeństwie. Ten środek oddziaływania penitencjarnego ma duże znaczenie dla sytuacji materialnej osoby skazanej i jej rodziny, ponieważ zarobki przyczyniają się do poprawienia statusu materialnego oraz umożliwiają wspieranie rodziny (Bilska 2004).

Skazana zatrudniona odpłatnie dostaje wynagrodzenie wynoszące przynajmniej połowę minimalnego wynagrodzenia za pracę, którą wykonuje na określonym stanowisku. Zatrudnienie stanowi wypełnienie jej czasu, przeciwdziała nudzie więziennej oraz bezczynności. Ma to duże znaczenie dla higieny psychicznej, gdyż osadzona czuje się potrzebna oraz uczy się pracy, a także współdziałania z innymi. Praca stanowi wtedy środek oddziaływania resocjalizacyjnego, kiedy powoduje u więźnia oczekiwane zmiany. Wyrobienie umiejętności oraz potrzeby pracy określa się jako wychowanie do pracy, zaś poprawa jakości pracy (np. dokładność, obowiązkowość) i przekonanie, iż praca, a nie przestępstwo, to sposób na życie, określa się jako wychowanie przez pracę. Praca umożliwia zachowanie sprawności 
zawodowej (sił fizycznych oraz umysłowych). Zatrudnienie - by stanowiło środek resocjalizacji - musi być poparte innymi metodami i środkami wychowawczymi (Szymanowska 2004, s. 199).

W teorii wszystkie te założenia wyglądają obiecująco, ale rzeczywistość jest niestety inna. Niepokojącą sprawę stanowi dziś zmniejszenie ilości miejsc pracy dla osób skazanych wewnątrz oraz na zewnątrz zakładów penitencjarnych. Kwestia zatrudnienia utraciła walor powszechności. Deficyt pracy działa w sposób demoralizujący, tworzy ogrom wolnego czasu, który trudno korekcyjnie zagospodarować. Zwiększeniu ulegają też wydatki ponoszone przez rodziny i przeznaczane na utrzymanie skazanego, tj. zakupy w kantynie czy koszty związane z przepustką itp.

\section{NAGRADZANIE I KARANIE WYCHOWAWCZE}

Chcąc efektywnie operować karą i nagrodą, wychowawca musi zapoznać się z potrzebami i aktualnymi dążeniami wychowanków. Pod uwagę należy również wziąć warunki, w jakich odbywa się procedura karania i nagradzania.

Ekonomia punktowa, o której tu mowa, stymuluje rozwój licznych wzmocnień pozytywnych dla osób odbywających karę pozbawienia wolności. Każda z placówek resocjalizacyjnych posiada swój regulamin dotyczący przyznawania punktów. Ten specyficzny system realizacji nagród oraz kar świadczy o niepowtarzalności i różnorodności zakładów. Zadaniem wychowawców danej jednostki jest ustalenie sposobów nagradzania oraz karania, zaś kolejnym - dokonywanie oceny stopnia ważności różnych przejawów zachowania oraz hierarchicznej strukturyzacji zachowań, dzięki czemu skazany otrzymuje nagrody bądź zostaje ukarany. Dobór właściwych wzmocnień dopasowany jest do cech osobowościowych wychowanka. Uwzględnione cechy rozpisywane są zgodnie z pięciostopniową skalą, w której 4 oznacza najkorzystniejsze, 3 - mniej korzystne, 2 - średnio korzystne, 1 - mało korzystne, 0 - niekorzystne (Pospiszyl 1998, s. 102-104).

Warto zaznaczyć, że karanie osadzonych często przynosi odwrotny do zamierzonego przez wychowawcę skutek. Coraz częściej bierze się pod uwagę jedynie nagrody, rezygnując z kar. Osadzony otrzymuje adekwatną ilość punktów do swojego zachowania.

Punkty, które uzyskał skazany, zamienia na żetony bądź specjalnie drukowane banknoty mające nominał stanowiący dowód liczby punktów, jaką osoba uzyskała (potoczna angielska nazwa terapii behawioralnej, która jest stosowana w praktyce brzmi: tokeneconomy, co dokładnie oznacza ekonomię żetonów) (Pospiszyl 2009, s. 52). 
W resocjalizacji zamkniętej cały wysiłek wychowawców koncentruje się na tym, by zachowanie skazanego było zgodne $\mathrm{z}$ regulaminem, nie poprzestaje on tylko na pilnowaniu. Zwraca się również szczególną uwagę na oddziaływania psychoterapeutyczne oraz próby utożsamiania się z nowo wyuczonymi postawami i poglądami osadzonych. Niezwykle istotne jest kontrolowanie i utrzymywanie porządku pośród skazanych, można tam znaleźć elementy wykorzystywane w systemie o charakterze dyscyplinarno-izolacyjnym, dominują zakazy oraz nakazy. Celem głównym jest wyeliminowanie roszczeniowo-destruktywnych cech oraz utrwalenie zachowania, które jest zgodne z przyjętymi normami społecznymi. Zaletą ekonomii punktowej wykorzystywanej w zakładach karnych jest ewentualność przyznawania punktów za pracę indywidualną lub grupową. Do wad należy zaliczyć przymusowe ponoszenie odpowiedzialności zbiorowej, która wywołuje bunt wśród skazanych. Wynikającą korzyścią jest nauka współpracy oraz odpowiedzialności - zacieśnia ona więzi międzyludzkie. Prowadzenie do integracji grupy jest szansą naprawiania uszczerbków osobowościowych podopiecznego przez naukę empatii, myślenia z punktu widzenia drugiego człowieka, szanowania praw innej osoby, a więc tego, co jest nieodzowne w funkcjonowaniu na wolności.

W praktyce penitencjarnej realizuje się dużą liczbę rozmaitych programów, najczęściej autorskich, jednak nie dzieje się tak we wszystkich placówkach. Należy więc zadbać o objęcie nimi jak największej liczby skazanych po to, by wychowanie resocjalizacyjne nie ograniczyło się tylko do „przechowywania” więźniów do czasu ich uwolnienia.

\section{LITERATURA}

Bilska. E., 2004, Jak Feniks z popiołów, czyli syndrom wypalenia zawodowego. „Niebieska Linia”, nr 4 [pozyskano z: http://www.niebieskalinia.pl/pismo/wydania/dostepne-artykuly/4422-jak-feniks-z-popiolow-czyli-syndrom-wypaleniazawodowego].

Błachut J., 2001, Płeć a przestępczość. W: J. Błachut, M.Szewczyk, J.Wójcikiewicz (red.), Nauka wobec przestępczości. Księga ku czci Prof. T. Hanauska. Kraków, Instytut Ekspertyz Sądowych.

Cabalski M., 2014, Przemoc stosowana przez kobiety. Studium kryminologiczne. Kraków, Impuls.

Gierowski J.K., 1989, Motywacja zabójstw. Kraków, Wydawnictwo AM.

Goldstein A.P, Glick B., Gibbs J.C., 2004, ART Program Zastępowania Agresji. Warszawa. 
Goźlińska A., 2013, Kobieta-zbrodniarka, czyli problematyka przestępczości kobiet, opublikowano: http://krytyka.org/kobieta-zbrodniarka-czyli-problematykaprzestepczosci-kobiet/ [dostęp: 27.12.2015].

Kwieciński J., Waligóra B., 2007, Zatrudnienie w strategii readaptacji społecznej skazanych - na przykładzie Zakładu karnego we Wronkach. W: B. Skafiriak (red.), Pomoc postpenitencjarna w kontekście strategii dziatań resocjalizacyjnych. Kraków, Oficyna Wydawnicza Impuls.

Machel H., 2006, Sens i bezsens resocjalizacji penitencjarnej - casus polski. Studium penitencjarno-pedagogiczne. Kraków, Oficyna Wydawnicza Impuls.

Mellibruda J., Charakterystyka zjawiska przemocy w rodzinie, opublikowano: http:// www.niebieskalinia.pl/przewodnik_ustawa/poradnik_eksperci_radza/01._Jerzy_Mellibruda.pdf [dostęp: 27.12.2015].

Morawski J., 2004, Trening Zastępowania Agresji w szkołach i placówkach systemu oświaty. Warszawa, Instytut Amity.

Pospiszyl I., 2008, Przemoc w rodzinie. W: B. Urban, J.M. Stanik (red.), Resocjalizacja. Warszawa, PWN.

Pospiszyl K., 2009, Resocjalizacja. Warszawa, Wydawnictwo Akademickie Żak.

Pospiszyl K., 1998, Resocjalizacja. Teoretyczne podstawy oraz przykłady programów oddziaływań. Warszawa, Wydawnictwo Akademickie Żak.

Potempska E., Kołodziejczyk A., 2001, Trening zastępowania agresji. Remedium, opublikowano: http://www.parpa.pl/download/trening1.pdf [dostęp 27.12.2015].

Pytka L., 1991, Pedagogika resocjalizacyjna. Wybrane zagadnienia teoretyczne i metodyczne. Warszawa, WSPS im. Marii Grzegorzewskiej.

Szymanowska A., 2004, Wykonywanie kary pozbawienia wolności w świetle wyników badań kryminologiczno-psychologicznych. W: W.F. Kozaczuk (red.), Resocjalizacja instytucjonalna: perspektywy i zagrożenia. Rzeszów, Wydawnictwo Uniwersytetu Rzeszowskiego.

\title{
REHABILITATION OF WOMEN IMPRISONED FOR CRIMES COMMITTED ON THE VIOLENCE BACKGROUND
}

\begin{abstract}
The primary objective of rehabilitational education is bringing to the individual the proper adaptation to living in the society as well as formatting personality features, habits and behaviour that allow the individual independent and appropriate functioning in the society. Women who have committed various crimes on the violence background, in penitentiaries, are subjected to a wide range of actions aiming to develop a specific, intended change or modify aggressive behaviours. The basic forms of influence in this area allow the contact with the family or being mother and child together in one prison, rehabilitation through work, participation
\end{abstract}


in numerous treatment programs dedicated to people using violence and aggression as well as rewarding and penalizing according to the principles of economics. Experiences of various penitentiaries prove the efficiency and the need to conduct such activities.

Keywords: motivations for crimes, personality model of female criminal, acts of violence, rehabilitational education, rehabilitation programs. 